\title{
Kepadatan Nerita sp Di Perairan Pantai Negeri Suli Teluk Baguala Kabupaten Maluku Tengah
}

\section{Sintje Liline $^{1 *}$, Muhammad Tarmizi Kubangun", Tri Santi Kurnia ${ }^{1}$, Wa Nurul Mutmainah Jainudin Heremba ${ }^{2}$ \\ ${ }^{1}$ Staf Pengajar Program Studi Pendidikan Biologi, FKIP Universitas Pattimura \\ ${ }^{2}$ Mahasiswa Program Studi Pendidikan Biologi, FKIP Universitas Pattimura \\ *E-mail: sinline28@gmail.com}

\begin{abstract}
Abstrak: Negeri Suli di Teluk Baguala Kabupaten Maluku Tengah memiliki perairan dengan tipe substrat yang beragam yaitu berpasir, berlumpur dan berbatu yang kaya organisme bentik. Salah satunya adalah gastropoda jenis Nerita $s p$ yang banyak dimanfaatkan oleh penduduk untuk kebutuhan pangan. Keberadaan gastropoda khususnya Nerita sp perlu dijaga dan lestarikan sehingga keanekaragaman dan kepadatan Nerita $s p$ dapat terjaga dan terpelihara dengan baik. Penelitian ini bertujuan untuk mengetahui jenis dan kepadatan Nerita sp di perairan pantai negeri Suli teluk Baguala kabupaten Maluku Tengah. Penelitian ini adalah penelitian deskriptif yaitu penelitian untuk mengungkapkan informasi tentang kepadatan Nerita $s p$ di perairan pantai negeri Suli Teluk Baguala kabupaten Maluku Tengah yang disajikan dalam bentuk tabel dan angka dan penelitian dilaksanakan pada bulan Juli 2019. Berdasarkan deskripsi morfologi Nerita sp. dari negeri Suli termasuk dalam spesies Nerita chamaeleon. Jumlah keseluruhan Nerita chamaeleon yang ditemukan adalah 566 individu dengan nilai kepadatan 11,32 dan dikategorikan kepadatannya cukup. Perlu dilakukan penelitian lanjut tentang kandungan gizi dan pemanfaatannya oleh masyarakat negeri Suli.
\end{abstract}

\section{Kata Kunci: Kepadatan, Nerita sp, Negeri Suli.}

Abstract: Suli in Baguala Bay, Central Maluku Regency has waters with various types of substrates, namely sandy, muddy and rocky which are rich in benthic organisms. One of them is the gastropod type Nerita $s p$ which is widely used by the population for food needs. The existence of gastropods, especially Nerita $s p$ needs to be maintained and preserved so that the diversity and density of Nerita $s p$ can be maintained and well maintained. This study aims to determine the type and density of Nerita $s p$. In the coastal waters of Suli, Baguala Bay, Central Maluku district. This research is a descriptive study, namely research to reveal information about the density of Nerita sp in the coastal waters of Suli Baguala Bay, Central Maluku district which is presented in the form of tables and numbers and the research was conducted in July 2019. Based on the description of the morphology of Nerita sp. from the land of Suli, including the species Nerita chamaeleon. The total number of Nerita chamaeleon found was 566 individuals with a density value 
of 11.32 and categorized as having sufficient density. It is necessary to do further research on the nutritional content and its use by the people of Suli.

\section{Keywords: Density, Nerita sp, Suli}

Moluska adalah salah satu organisme yang mempunyai peranan penting dalam fungsi ekologis pada ekosistem perairan, diantaranya adalah Gastropoda. Gastropoda umumnya hidup di laut tetapi ada sebagian yang hidup di darat dan mempunyai peranan yang penting baik dari segi ekologi maupun ekonomi. Secara ekologi berperan sebagai konsumen, contohnya adalah Cellanaradiata dan secara ekonomi cangkangnya dapat digunakan untuk berbagai hiasan yang mahal, seperti Cypraea, Murex, dan Trochus. Selain itu, dapat berperan sebagai sumber bahan makanan seperti Cymbiola dan Nerita yang diambil dagingnya untuk dikonsumsi (Dharma, 1988).

Nerita sp. atau bia, sebutan umum masyarakat di Ambon, merupakan hewan laut yang biasanya dikonsumsi masyarakat pulau Ambon dan digemari masyarakat di pulau Ambon sebagai salah satu sumber makanan alternatif selain ikan. Nerita sp. sering dikonsumsi terutama pada saat musim ombak dimana ikan sulit didapat dan diambil pada saat air laut surut, disebut dengan bameti. Daerah yang menjadi aktivitas masyarakat pulau Ambon untuk bameti Nerita sp. adalah di perairan negeri Suli teluk Baguala kabupaten Maluku Tengah.

Perairan Negeri Suli di Teluk Baguala kabupaten Maluku Tengah merupakan perairan dengan tipe substrat yang beragam yaitu berpasir, berlumpur dan berbatu (patahan karang mati) yang kaya organisme bentik. Salah satunya adalah gastropoda jenis Nerita sp. yang banyak dimanfaatkan oleh penduduk untuk kebutuhan pangan dan dapat memberikan dorongan untuk mencari sumberdaya perikanan baru di laut. Adanya sumberdaya tersebut tentunya memberikan harapan khusus bagi masyarakat yang hidup di daerah pesisir guna memanfaatkan sumberdaya tersebut untuk konsumsi sehari-hari (Supusepa, 2018). Untuk itu, keberadaan gastropoda khususnya Nerita sp. perlu kita jaga dan lestarikan sehingga keanekaragaman dan kepadatan jenis dari Nerita sp. tersebut dapat terjaga dan terpelihara dengan baik. Penelitian ini bertujuan untuk mengetahui jenis dan kepadatan Nerita sp. di perairan pantai negeri Suli teluk Baguala kabupaten Maluku Tengah

\section{METODE PENELITIAN}

Penelitian ini adalah penelitian deskriptif yaitu penelitian untuk mengungkapkan informasi tentang kepadatan Nerita $s p$. di perairan pantai negeri Suli Teluk Baguala kabupaten Maluku Tengah yang disajikan dalam bentuk tabel dan angka dan penelitian dilaksanakan pada bulan Juli 2019. Populasi dalam penelitian ini adalah semua Nerita sp. yang terdapat di perairan pantai negeri Suli Teluk Baguala kabupaten Maluku Tengah. 
Teknik penentuan sampel dilakukan secara purposive sampling dan sampel yang digunakan dalam penelitian ini adalah Nerita $s p$. yang terdapat dalam petak pengamatan di perairan pantai negeri Suli Teluk Baguala kabupaten Maluku Tengah dengan luas daerah pengamatan adalah $5 \mathrm{~m} \mathrm{X} 10 \mathrm{~m}=50 \mathrm{~m}^{2}$. Penghitungan kepadatan Nerita sp. perairan pantai negeri Suli Teluk Baguala kabupaten Maluku Tengah dengan menggunakan rumus:

Kepadatan populasi dinyatakan dengan jumlah individu per $\mathrm{m}^{2}$. Kepadatan dihitung dengan menggunakan rumus menurut Krebs (1978).

Kepadatan Absolut $(\mathrm{KA})=\frac{\text { Jumlah individu suatu jenis }}{\text { Luas area yang berisi jenis }}$

Kepadatan relatif $(\%)(\mathrm{KR}) \quad=\frac{\text { Densitas suatu jenis }}{\text { Jumlah total densitas seluruh jenis }} \times 100 \%$

Kepadatan jenis dikategorikan menurut Cox (1967) sebagai berikut:

\begin{tabular}{|c|l|}
\hline 0 & $=$ tidak ada \\
\hline $1-10$ & $=$ kurang \\
\hline $11-20$ & $=$ cukup \\
\hline$>20$ & $=$ sangat banyak \\
\hline
\end{tabular}

\section{HASIL DAN PEMBAHASAN}

\section{Deskripsi Lokasi Penelitian}

Perairan Negeri Suli merupakan perairan yang termasuk dalam Kecamatan Salahutu Kabupaten Maluku Tengah. Perairan Negeri Suli memiliki pantai pasir putih dengan tipe substratnya yang beragam yaitu pasir, berlumpur dan berbatu yang merupakan patahan karang mati. Substrat yang mendominasi daerah penelitian adalah pasir berlumpur dan patahan karang. Pada lokasi ini ditemukan padang lamun yang terbentang luas dan juga terdapat ekosistem mangrove. Pada daerah padang lamun banyak ditemukan organisme-organisme yang berasosiasi dengan padang lamun antara lain ikan, ular laut, bulu babi, bintang laut, kepiting, algae, bivalvia dan salah satu satu sumberdaya yang juga dimanfaatkan oleh masyarakat yaitu gastropoda. Pada ekosistem mangrove banyak juga ditemukan gastropoda yang menempel pada batang dan akar mangrove maupun gastropoda yaitu Nerita $s p$. yang menempel pada batu-batuan (karang mati) di sekitar akar mangrove. Secara geografis negeri Suli berada pada kecamatan Salahutu kabupaten Maluku Tengah pada kedudukan $3^{\circ} 15^{\prime}-3^{\circ} 40^{\prime}$ LS dan $126^{\circ} 30^{\prime}-127^{\circ}$ BT, sebelah 
Utara berbatasan dengan gunung Salahutu, sebelah selatan dengan teluk baguala, sebelah timur dengan negeri Tulehu dan Tial, sebelah Barat dengan Desa Passo.

\section{Morfologi Nerita sp. di Perairan Pantai Negeri Suli}

Nerita $s p$. yang ditemukan di perairan pantai Negeri Suli menempel pada batubatuan kecil (karang mati) yang banyak terdapat di sekitar akar mangrove dapat dilihat pada Gambar 1.

\begin{tabular}{|c|c|c|}
\hline $\begin{array}{c}\text { Kode } \\
\text { Spesies }\end{array}$ & Cangkang & Operculum \\
\hline $\mathrm{S}$ & $\begin{array}{l}\text { SL : } 20,31 \mathrm{~mm} \\
\mathrm{SW}: 19,75 \mathrm{~mm} \\
\mathrm{AL}: 9,50 \mathrm{~mm} \\
\mathrm{AW}: 3,39 \mathrm{~mm}\end{array}$ & \\
\hline
\end{tabular}

Gambar 1. Cangkang dan Operculum Nerita sp. dari Negeri Suli (Sumber: Dokumentasi, 2019)

Sampel S memiliki karakteristik morfologi dengan cangkang yang berwarna coklat muda dengan bercak-bercak secara acak pada cangkang berwarna coklat tua, hitam dan putih, permukaan cangkang bergerigi kasar dengan garis-garis spiral, puncak cangkang mencuat dan tinggi, terdapat gerigi pada bibir luar cangkang, operculum berwarna coklat sampai coklat tua, permukaan luar operculum berbintil-bintil dan cekung, panjang cangkang 20,31 mm, lebar cangkang 19,75 mm, panjang aperture 9,50 mm dan lebar aperture 3,39 mm. Hidup dengan menempel pada permukaan karang mati. Berdasarkan pengamatan morfologi yang dilakukan, maka sampel dapat digolongkan ke dalam spesies Nerita chamaeleon.

Karakteristik morfologi $N$. chamaeleon, yaitu seluruh permukaan luar operculum yang cekung dan berbintil-bintil, permukaan cangkang dengan garis-garis spiral, kalus berbintil-bintil, gerigi pada bibir luar besar dan jumlahnya > 15 gigi, puncak cangkang hanya sedikit mencuat (Vermeij, 1984; Frey dan Vermeij, 2008; Frey, 2010a). 


\section{Kepadatan Nerita sp. di Perairan Pantai Negeri Suli}

Jenis Nerita $s p$. yang ditemukan di perairan pantai negeri Suli hanya 1 jenis dan dari morfologi dapat disimpulkan sebagai Nerita chamaeleon. Jumlah keseluruhan Nerita chamaeleon yang ditemukan adalah 566 individu dengan nilai kepadatan 11,32 dan dikategorikan kepadatannya cukup (Fox, 1967).

Tabel 1. Nilai Kepadatan Nerita sp. dari Perairan Pantai Negeri Suli

\begin{tabular}{|l|c|c|c|}
\hline \multicolumn{1}{|c|}{ Jenis } & Jumlah Individu & $\begin{array}{c}\text { Kepadatan } \\
\text { Absolut }\end{array}$ & Kepadatan Relatif \\
\hline Nerita chamaeleon & 566 & 11,32 & 100 \\
\hline
\end{tabular}

Nerita chamaeleon yang ditemukan di perairan pantai Negeri Suli memiliki nilai kepadatan cukup karena kondisi perairan yang mendukung kehadirannya, tersedianya bahan organik, serta didukung oleh kondisi substrat berpasir dan terdapat batu-batuan kecil (karang mati) di sekitar akar mangrove sebagai tempat menempel. Nilai kepadatan dipengaruhi oleh kondisi habitat yang optimum untuk kehidupan Nerita sehingga Nerita mampu berkembang biak dengan baik. Hal ini sejalan dengan pernyataan Odum (1996) bahwa nilai kepadatan suatu spesies tergantung pada kemampuan spesies menempati ruang yang lebih luas sehingga memiliki kemampuan berkembang lebih banyak. Sedangkan Carpenter (1988) menjelaskan bahwa nilai kepadatan jenis rendah karena adanya kompetisi atau pemangsa, lingkungan fisik, dan kimia perairan yang kurang baik sehinga dapat menyebabkan perbedaan dalam kepadatan.

\section{KESIMPULAN}

Berdasarkan hasil penelitain, maka dapat disimpulkan bahwa spesies Nerita yang ditemukan di perairan pantai desa Suli adalah Nerita chamaeleon dengan nilai kepadatan 11,32 dan dikategorikan kepadatannya cukup.

\section{DAFTAR PUSTAKA}

Carpenter, E.K. \& V.H. Niem, (1988). The Living Marine Resource of The Western Central Pasifik. Vol 1. Seaweed, Corals, Bivalves, and Gastropod. New York: Food and Agriculture Organizations.

Cox, G.W. (1967). Laboratory Manual of General Ecology. Brown Company Publisher. USA.

Dharma, B. (1988). Siput dan Kerang Indonesia (Indonesia Shells). PT Sarana Graha. Jakarta.

Frey, M.A. and G.J. Vermeij. (2008). Molecular Phylogenies and Historical Biogeography of a Circumtropical Group of Gastropods (genus: Nerita): Implications for Regional Diversity Patterns in the Marine Tropics. Molecular Phylogenetics and Evolution 48: 1067-1086. 
Frey, M.A. (2010a). A Revised Classification of the Gastropod Genus Nerita. The Veliger 51(1): $1-7$.

Odum, E. P. (1996). Dasar-dasar Ekologi. Gadjah Mada University Press. Yogjakarta. Supusepa, J. (2018). Inventaris Jenis Dan Potensi Gastropoda Di Negeri suli Dan Negeri Tial. Jurnal TRITON Volume 14, Nomor 1, April 2018, hal.28-34.

Krebs, C.J. (1978). Ecology of Experimental Analysis of Distribution and Abundance. Second edition. New York: Harper and Row Publishers.

Vermeij, G.J. (1984). The Systematic Position of the Neritid Prosobranch gastropod Nerita polita and Related Species. Proceedings Biological Society of Washington 97(4): 688-692. 